\title{
GROWTH PATTERN OF FLOUNDER, PLATICHTHYS FLESUS (L.), FROM THE GULF OF GDAŃSK (SOUTHERN BALTIC SEA)
}

\author{
Artur ANTOSZEK*, Stanisław KRZYKAWSKI \\ Division of Fish Systematics, Agricultural University of Szczecin, Poland
}

Antoszek A., Krzykawski S., 2005. Growth pattern of flounder, Platichthys flesus (L.), from the Gulf of Gdańsk (southern Baltic Sea). Acta Ichthyol. Piscat. 35 (1): 51-60.

Background. It is a common perception that growth rates of many commercially-exploited fish species have been well known. It is evident, however, that in certain cases, especially in brackish water environments those growth rates may be diversified. Therefore, determination of growth patterns of various stocks of the same fish, living in different salinity regimes may be important for efficient fisheries management, especially fish-quotas negotiations. The aim of the presently reported study was to estimate the growth rates of length and weight of flounder Platichthys flesus (L.) from the Gulf of Gdańsk and to compare them with those from the Pomeranian Bay and Słupsk Furrow areas.

Materials and methods. A total of 200 fish, collected in the coastal waters of Hel in 1997, was analysed. The fish were caught using flatfish gill nets. The age of flounder was determined from otoliths, whereas measurements of the annual ring increments were made using a dissecting microscope with reflected light over a dark background. The microscope was outfitted with a camera and linked to computer. The images were processed using an image-processing software "Multiscan". The method of Vovk was employed to study the growth rate of flounder, both for the whole sample and in relation to both sexes. The calculation of the growth rates of length and weight were aided by the equations of von Bertalanffy.

Results. The total length of the flounder studied ranged from 4.3 to $46.0 \mathrm{~cm}$ for ages from one through ten. The mean length reached $23.7 \mathrm{~cm}$, while the mean age was 4.6 years. The prevalent age classes were III, IV, and V. The growth rates of length were different in males and females. Until the third year of life males grew slightly faster, while from the fourth year, the females grew more rapidly. The von Bertalanffy equations that describe theoretical growth (length and weight) of flounder, from the Gulf of Gdańsk were calculated.

Conclusion. The differences found in the morphometric and biological characters between the samples collected in three different locations of the southern Baltic (Pomeranian Bay, Słupsk Furrow, and Gulf of Gdańsk) may indicate that they represent separate stocks (populations).

Key words: flounder, age, length, weight, growth rate, Pomeranian Bay, Słupsk Furrow, Gulf of Gdańsk, southern Baltic

\section{INTRODUCTION}

The landings of flatfishes (Pleuronectiformes) in the FAO area of north-eastern Atlantic, within 1996-2002, ranged from 9765 to $23380 \mathrm{t}$. They constituted up to $0.15 \%$ of the total catch from this area. The highest flatfish landings were recorded from 1997 through 1998 (Anonymous 2004).

The contribution of flatfishes to Polish fish landings in the Baltic Sea tends to increase. Within 2000-2002 it increased from $4.0 \%$ to $6.3 \%$ of the total weight of all fishes captured there (Miłosz et al. 2003).

The flounder, Platichthys flesus (L.), is one of the most commercially important flatfishes that occur in the Baltic Sea. Flounder used to be the most important component of flatfish catches in the Baltic, in both Polish- and neighbouring zones. Within 1989-1994, flounder constituted from $85 \%$ to $99 \%$ (depending on the area of capture) of all Polish flatfish landings (by weight) (Kuczyński 1996).

There has been a number of papers focused on the biology of the Baltic flounder, although many of them were published in the 1930s and 1940s (e.g. Cięglewicz 1935, 1947, Cięglewicz et al. 1969). The literature, appearing within the last decade, was based predominately on the flounder landings (e.g. Kuczyński 1992, 1995, 1996).

A revived interest in the Baltic flounder, however, could be observed in recent years (Antoszek and Krzykawski 2003, 2004). The above-mentioned papers dealt with morphometry and growth patterns of flounder from the southern Baltic (Pomeranian Bay and Slupsk Furrow). The above-mentioned characteristics, significant from the taxonomic point of view, are also essential for fisheries management and sustainable exploitation of this species.

\footnotetext{
* Correspondence: Dr Artur Antoszek, Zakład Systematyki Ryb, Wydział Nauk o Żywności i Rybactwa, Akademia Rolnicza w Szczecinie, ul. Kazimierza Królewicza 4, 71-550 Szczecin, Poland, e-mail: antosz@fish.ar.szczecin.pl
} 
The objective of the presently reported study was to assess the growth rates of length and weight of flounder collected from the Gulf of Gdańsk. Also, distributions of length and age of flounder were presented, as well as the length-weight relationship was determined. The results obtained were compared with the available data (following the same standard procedures) on flounder from the Pomeranian Bay (Antoszek and Krzykawski 2003) and from the Słupsk Furrow (Antoszek and Krzykawski 2004).

\section{MATERIAL AND METHODS}

A total of 200 flounder was collected in 1997, in the coastal waters off the village of Hel (Gulf of Gdańsk) by small fishing vessels, using flatfish gill-nets (Fig. 1). The detailed description of fish studied is given in Table 1. The fish caught were frozen and sent to Szczecin to the laboratory of the Division of the Fish Systematics. The biometric analysis was made on the thawed material, performed for the whole sample and for both sexes. All measurements were made with a slide caliper, to the nearest $0.1 \mathrm{~cm}$. The weight (of ungutted fish only) was determined with the accuracy of $0.1 \mathrm{~g}$.

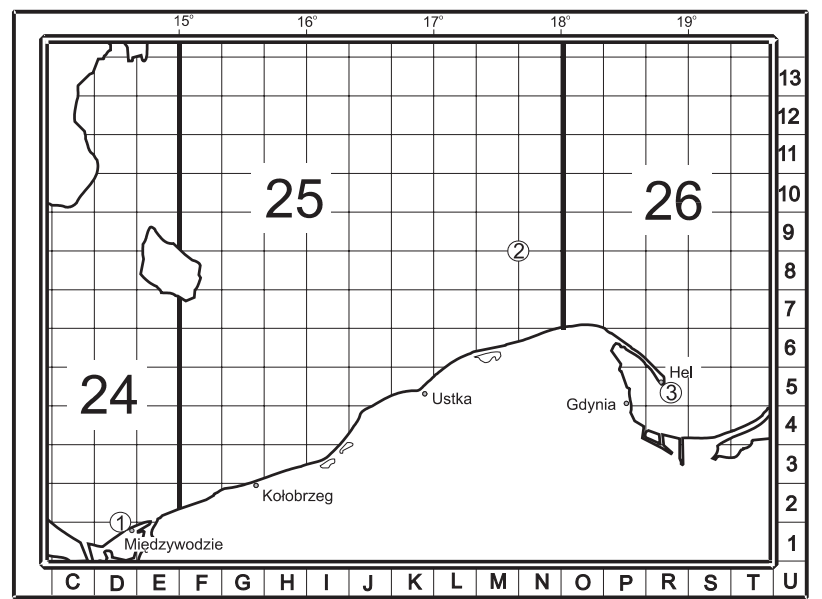

Fig. 1. Location of flounder sampling sites referred to in Discussion 1 - Sample from the Pomeranian Bay (Antoszek and Krzykawski 2003) 2 - Sample from the Słupsk Furrow (Antoszek and Krzykawski 2004) 3 - Sample from the Gulf of Gdańsk (presently reported study)

The age of individuals examined in the present study was derived from otolith analysis, following Draganik and Kuczyński (1993). Whole sagittae were examined in water, using a dissecting microscope with reflected light over a dark background (Cięglewicz et al. 1969, Draganik and Kuczyński 1993). Measurements of annual growth increments were made to the nearest $0.01 \mathrm{~mm}$, with the reference to nucleus. The dissecting microscope used, was linked to a computer with a measuring- and image-processing software "Multiscan".

As the total length (TL)-otolith radius (OR) relationship was curvilinear, the method of Vovk (1956) was used to determine the growth rate of flounder's length by back-calculated reading. Length values calculated by this method, as empirical values, were employed to show a growth rate of flounder in von Bertalanffy model (Ricker 1975). All measurements were performed using MS Excel macro platform. The alternative Fi SAT software is also known by the present authors, although it was not used because it is restricted to users of WINDOWS operating system.

The length-weight relationship was determined based on the mean weights calculated in the particular length classes (2-cm interval). Weights estimated by this relationship allowed to show a growth pattern of weight of flounder with the modified von Bertalanffy model; however instead of exponent equalling " 3 ", the value of coefficient " $n$ " was introduced, estimated from the length-weight relationship what allowed to obtain results approximate the empirical data.

Minet (1973) showed the growth rate of weight of American plaice with the von Bertalanffy model using similar procedures like in the present paper.

\section{RESULTS}

Distributions of total length (TL) and age of the flounder studied (200 fish), with respect to sexes, are presented in Fig. 2.

The total length of flounder males (113 individuals) was $14.9-35.6 \mathrm{~cm}$, with the mean length of $22.2 \mathrm{~cm}$. The most numerous was the $20-21.9 \mathrm{~cm}$ length class, with $35.4 \%$ of males.

Females (86 specimens) were $12.3-46.0 \mathrm{~cm}$ long (TL); the mean length $(25.9 \mathrm{~cm})$ was higher than in males. The length class of $20-21.9 \mathrm{~cm}$ was the most numerous (18\% of females).

The total length (TL) of all fish examined ranged from 4.3 to $46.0 \mathrm{~cm}$, with the mean value of $23.7 \mathrm{~cm}$. The most numerous was the $20-21.9 \mathrm{~cm}$ length class (TL) $(28.0 \%$ of whole sample).

Table 1

Characteristics of flounder sample collected

\begin{tabular}{cc}
\hline Period of capture & May-July 1997 \\
Males number & 113 \\
Females number & 86 \\
Total number & $200^{*}$ \\
Right-eyed fish number & $148(74 \%)$ \\
Range of total length (TL) $[\mathrm{cm}]$ & $4.3-46.0$ \\
Mean length (TL) [cm] & 23.7 \\
Range of weight $[\mathrm{g}]$ & $01-1240$ \\
Range of age & $\mathrm{I}-\mathrm{X}$ \\
\hline
\end{tabular}

* one specimen unsexed 

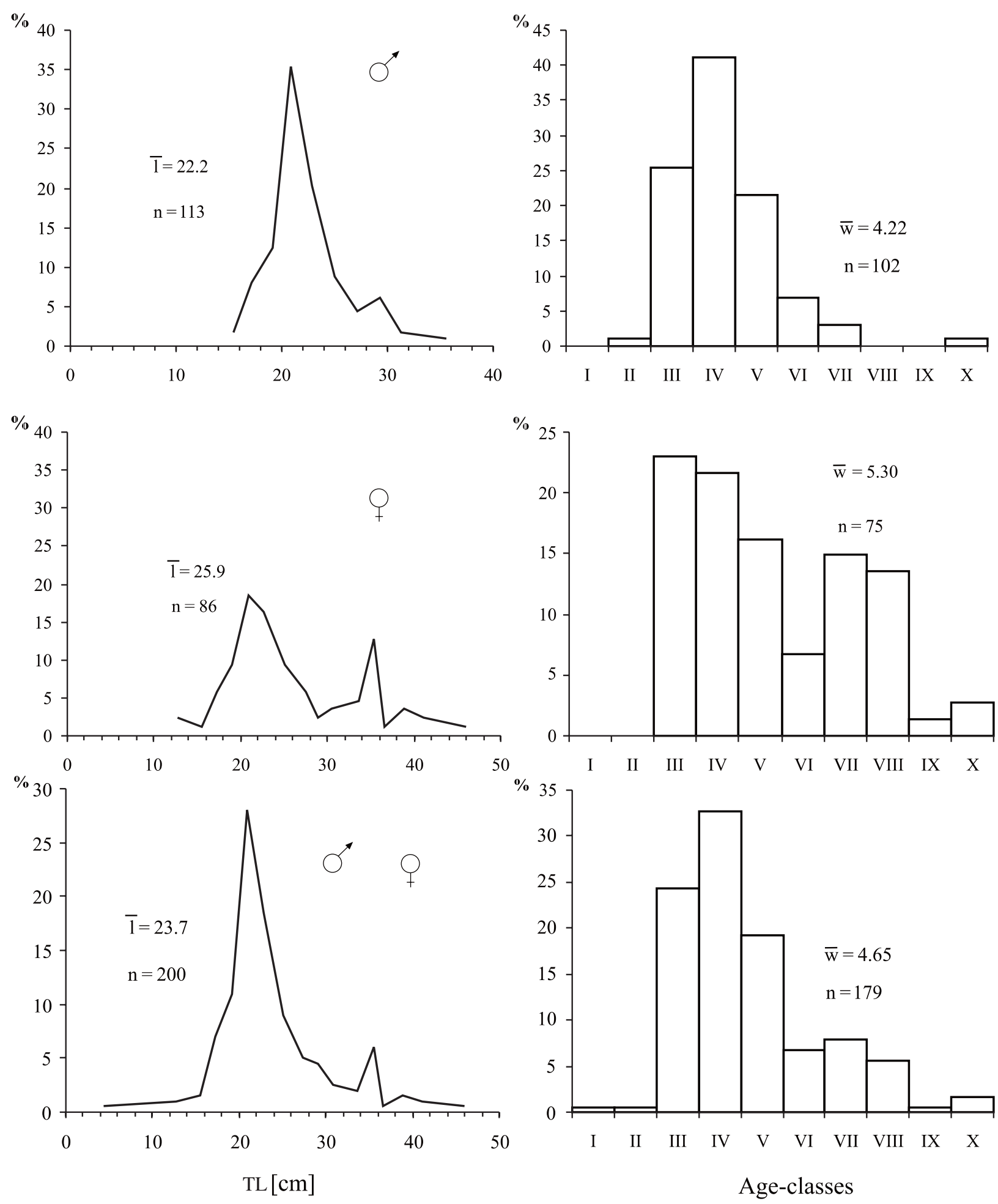

Fig. 2. Distribution of total length (TL) and age structure of fish examined

Males predominated in the sample studied. The age of the fish studied ranged from one to ten. Four-year-old specimens were the most abundant in the whole sample. Also four-yearold males where the most numerous, with age groups eight and nine absent altogether. In females, the range of age was narrower (three-ten) with III and IV age-classes prevailing. The mean age of females was higher by one year when compared to males. The smallest fish in the sample $(4.3 \mathrm{~cm} \mathrm{TL})$ was immature and unsexed, included to I age-class.
Because Antoszek and Krzykawski (2003) showed that the total length (TL)-otolith radius (OR) relationship in the flounder was curvilinear, the method of Vovk (1956) was used to determine the growth rate of flounder's length by back-calculated reading.

Back-calculated growth rates of length (TL) in males and females from the area studied are presented in Tables 2 and 3 .

As can be seen from Table 2, greatest increments of length $(\Delta \mathrm{L})$ in males were observed in the first- and sec- 
Growth rate of flounder males based on the back calculations (TL) [cm]

\begin{tabular}{|c|c|c|c|c|c|c|c|c|}
\hline \multirow{2}{*}{ Age-class } & \multicolumn{7}{|c|}{ Length at consecutive years of life } & \multirow{2}{*}{ Number of fish } \\
\hline & $l_{1}$ & $l_{2}$ & $l_{3}$ & $l_{4}$ & $l_{5}$ & $l_{6}$ & $l_{7}$ & \\
\hline II & 7.4 & 14.7 & & & & & & 1 \\
\hline III & 6.0 & 12.8 & 19.1 & & & & & 26 \\
\hline IV & 5.8 & 12.3 & 17.2 & 20.7 & & & & 42 \\
\hline $\mathrm{V}$ & 6.5 & 11.6 & 16.8 & 21.2 & 24.1 & & & 23 \\
\hline VI & 4.8 & 9.5 & 15.4 & 19.8 & 23.3 & 26.3 & & 7 \\
\hline VII & 6.1 & 11.8 & 18.1 & 23.4 & 26.9 & 29.4 & 31.6 & 3 \\
\hline $\bar{x}$ & 6.0 & 12.1 & 17.5 & 20.9 & 24.2 & 27.2 & 31.6 & $\sum 102$ \\
\hline$s$ & 1.5 & 2.5 & 2.5 & 2.2 & 2.8 & 3.2 & 3.5 & \\
\hline $\mathrm{CV}$ & 25.08 & 20.33 & 14.14 & 10.51 & 11.71 & 11.85 & 11.08 & \\
\hline$\Delta \mathrm{L}$ & 6 & 6.1 & 5.4 & 3.4 & 3.3 & 3.1 & 4.4 & \\
\hline $\mathrm{n}$ & 102 & 102 & 101 & 75 & 33 & 10 & 3 & \\
\hline
\end{tabular}

Growth rate of flounder females based on the back calculations (TL) [cm]

Table 3

\begin{tabular}{|c|c|c|c|c|c|c|c|c|c|c|c|}
\hline \multirow{2}{*}{ Age-class } & \multicolumn{10}{|c|}{ Length at consecutive years of life } & \multirow{2}{*}{$\begin{array}{c}\text { Number } \\
\text { of fish }\end{array}$} \\
\hline & $l_{1}$ & $l_{2}$ & $l_{3}$ & $l_{4}$ & $l_{5}$ & $l_{6}$ & $l_{7}$ & $l_{8}$ & $l_{9}$ & $l_{10}$ & \\
\hline III & 5.4 & 12.3 & 18.6 & & & & & & & & 17 \\
\hline IV & 5.1 & 10.9 & 16.5 & 20.8 & & & & & & & 16 \\
\hline $\mathrm{V}$ & 5.5 & 12.2 & 16.8 & 20.9 & 23.6 & & & & & & 12 \\
\hline VI & 6.3 & 11.1 & 15.7 & 19.8 & 23.7 & 26.6 & & & & & 5 \\
\hline VII & 5.9 & 9.9 & 15.9 & 21.1 & 26.3 & 30.4 & 32.2 & & & & 12 \\
\hline VIII & 7.3 & 11.7 & 16.3 & 21.8 & 26.1 & 30.1 & 33.3 & 35.6 & & & 10 \\
\hline IX & 5.4 & 15.2 & 24.1 & 30.2 & 33.2 & 35.1 & 36.8 & 38.5 & 40.2 & & 1 \\
\hline$X$ & 5.8 & 11.7 & 17.9 & 23.0 & 25.4 & 29.4 & 34.4 & 37.1 & 40.1 & 42.2 & 2 \\
\hline $\bar{x}$ & 5.8 & 11.5 & 17.0 & 21.2 & 25.3 & 29.8 & 33.0 & 36.0 & 40.1 & 42.2 & $\sum 75$ \\
\hline$s$ & 1.34 & 2.36 & 3.03 & 2.93 & 3.04 & 3.10 & 3.08 & 3.22 & 3.69 & 4.54 & \\
\hline $\mathrm{CV}$ & 23.19 & 20.57 & 17.83 & 13.82 & 12.01 & 10.41 & 9.34 & 8.93 & 9.20 & 10.75 & \\
\hline$\Delta \mathrm{L}$ & 5.8 & 5.7 & 5.5 & 4.2 & 4.1 & 4.5 & 3.2 & 3.0 & 4.1 & 2.1 & \\
\hline $\mathrm{n}$ & 75 & 75 & 75 & 58 & 42 & 30 & 25 & 13 & 3 & 2 & \\
\hline
\end{tabular}


ond years of life, then in consecutive years it tended to decrease, to slightly increase in the last year of life. The highest fluctuations of individual length were noted in the first year of life, what is indicated by the highest coefficient of variation $(\mathrm{CV})$.

In females (Table 3) the greatest increments of length were also seen in the first- and second years of life, then in the consecutive years it decreased gradually, except for the sixth- and ninth years, when the slight rises were noted. The highest fluctuations of length were noted in the first year of life. As can be seen from Tables 2 and 3, males to the third year of life were characterized by a little higher growth rate, whereas from the fourth year females grew faster.

The growth rate of length of fish in the whole material studied is shown in Table 4. As can be seen, the greatest increments of length of flounder were noted in the firstand second years of life, then in consecutive years (with some fluctuations) it tended to decrease. Coefficients of variability indicated the highest fluctuations of length in the first year of life.

Fig. 3 presents the curve of growth of length fitted with the von Bertalanffy equation; additionally, the annual increments are enclosed. Values of the von Bertalanffy equation were established on the basis of the empirical length values, attained in the consecutive years of life. Those data were taken from the sections from $l_{1}$ to $l_{8}$ of Table 4 . The mean lengths for $l_{9}$ and $l_{10}$ were omitted due to low number of fish in these age-classes.

Fig. 4 demonstrates the total length (TL)-weight $(W)$ relationship of the flounder studied, based on the averaged values of total length of fish, derived from the $2 \mathrm{~cm}$ length classes. The relationship between the total length (TL) and weight $(W)$ in the whole sample can be expressed as follows:

$$
W=0.0175 L^{2.9088}
$$

The individual mean weight in age-classes was calculated, introducing a mean length to the formula of total length (TL)-weight $(W)$ relationship. In Fig. 5 the growth rate of weight is shown, calculated with the modified von Bertalanffy equation:

$$
W_{\mathrm{t}}=3780\left[1-e^{-0.0915}\left(t+{ }^{0.0087}\right)\right]^{2.9088}
$$

Table 4

\begin{tabular}{|c|c|c|c|c|c|c|c|c|c|c|c|}
\hline \multirow{2}{*}{ Age-class } & \multicolumn{10}{|c|}{ Length at consecutive years of life } & \multirow{2}{*}{$\begin{array}{c}\text { Number } \\
\text { of fish }\end{array}$} \\
\hline & $1_{1}$ & $1_{2}$ & $1_{3}$ & $1_{4}$ & $1_{5}$ & $1_{6}$ & $1_{7}$ & $1_{8}$ & $1_{9}$ & $1_{10}$ & \\
\hline I & 4.2 & & & & & & & & & & 1 \\
\hline II & 7.4 & 14.7 & & & & & & & & & 1 \\
\hline III & 5.8 & 12.6 & 18.9 & & & & & & & & 43 \\
\hline IV & 5.6 & 11.9 & 17.0 & 20.7 & & & & & & & 58 \\
\hline $\mathrm{V}$ & 6.2 & 11.8 & 16.8 & 21.1 & 23.9 & & & & & & 35 \\
\hline VI & 5.4 & 10.2 & 15.5 & 19.8 & 23.5 & 26.4 & & & & & 12 \\
\hline VII & 6.0 & 10.3 & 16.3 & 21.5 & 26.4 & 30.2 & 32.1 & & & & 15 \\
\hline VIII & 7.3 & 11.7 & 16.3 & 21.8 & 26.1 & 30.1 & 33.3 & 35.6 & & & 10 \\
\hline IX & 5.4 & 15.2 & 24.1 & 30.2 & 33.2 & 35.1 & 36.8 & 38.5 & 40.2 & & 1 \\
\hline$X$ & 5.8 & 11.7 & 17.9 & 23.0 & 25.4 & 29.4 & 34.4 & 37.1 & 40.1 & 42.2 & 2 \\
\hline $\bar{x}$ & 5.9 & 11.8 & 17.3 & 21.0 & 24.8 & 29.1 & 32.9 & 36.0 & 40.1 & 42.2 & $\sum 178$ \\
\hline $\mathrm{s}$ & 1.44 & 2.43 & 2.73 & 2.54 & 2.98 & 3.28 & 3.09 & 3.22 & 3.69 & 4.54 & \\
\hline V & 24.41 & 20.59 & 15.78 & 12.10 & 12.02 & 11.27 & 9.39 & 8.94 & 9.20 & 10.76 & \\
\hline$\Delta \mathrm{L}$ & 5.9 & 5.9 & 5.5 & 3.7 & 3.8 & 4.3 & 3.8 & 3.1 & 4.1 & 2.1 & \\
\hline $\mathrm{n}$ & 178 & 177 & 176 & 133 & 75 & 40 & 28 & 13 & 3 & 2 & \\
\hline
\end{tabular}

Growth rate of sex combined of flounder based on the back calculations (TL) [cm] 


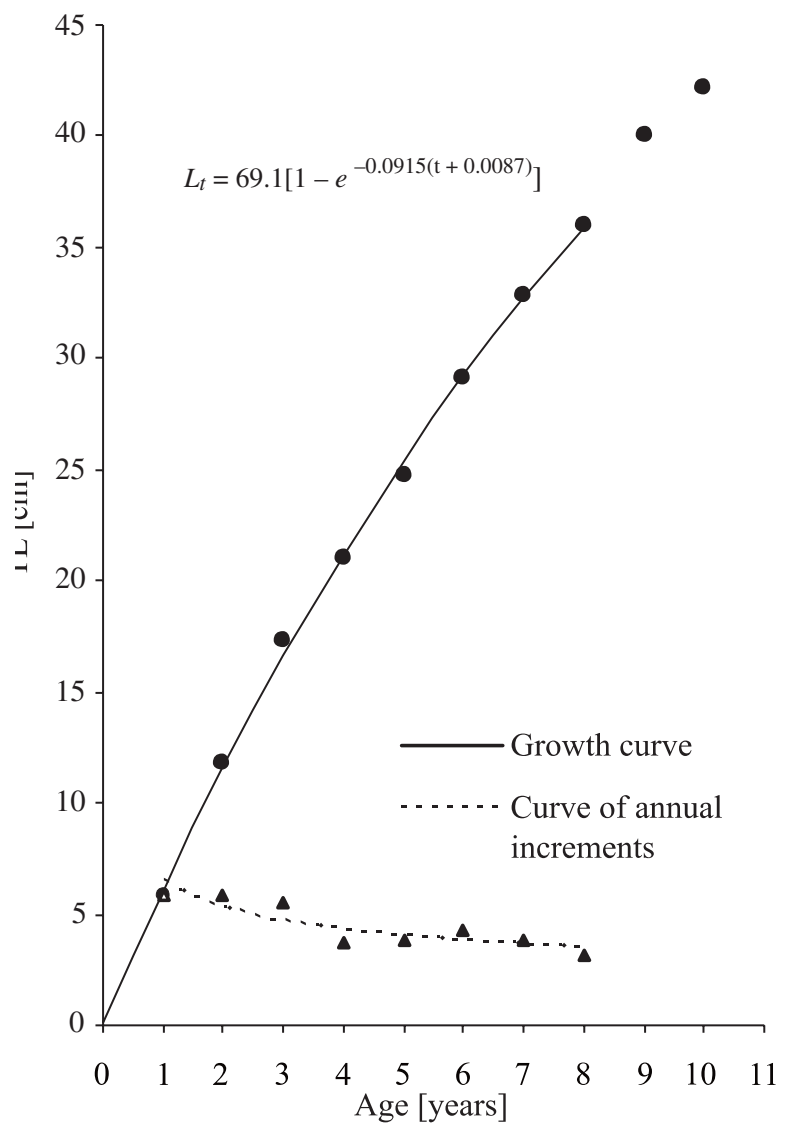

Fig. 3. The growth rate and curve of annual increments established with the von Bertalanffy equation; empirical values are marked with dots (back calculations results)

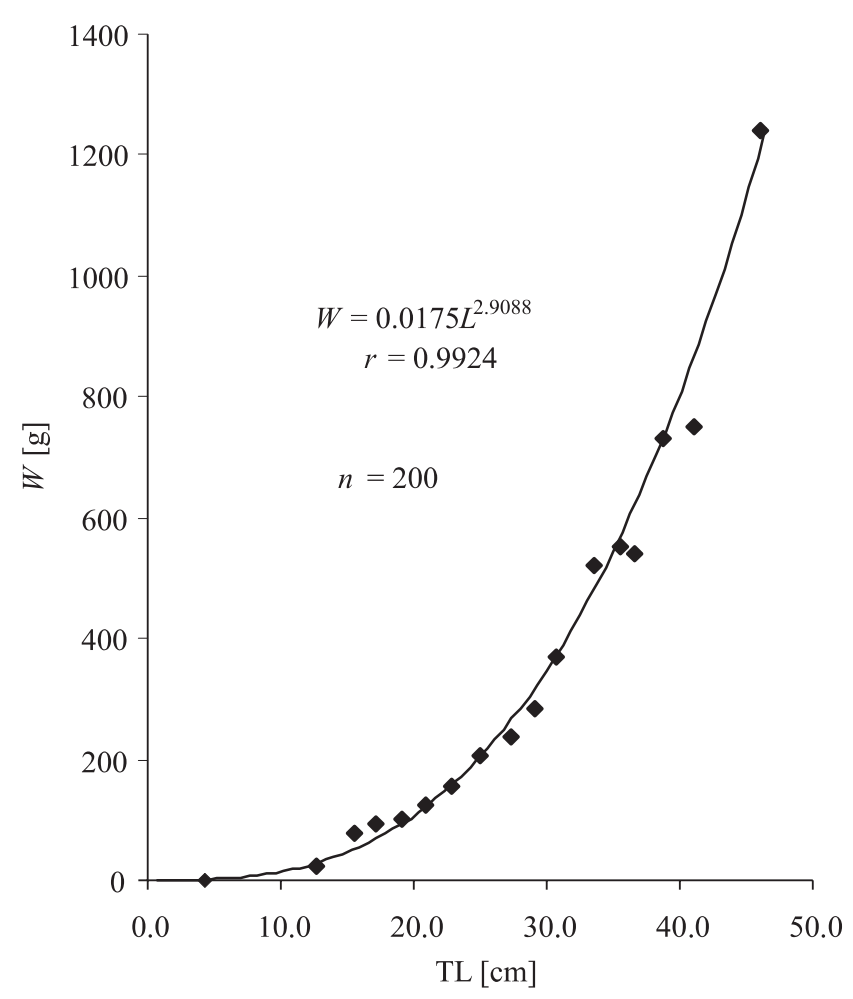

Fig. 4. Total length (TL) - weight of flounder; $(W)$ relationship (mean weights in the length classes)

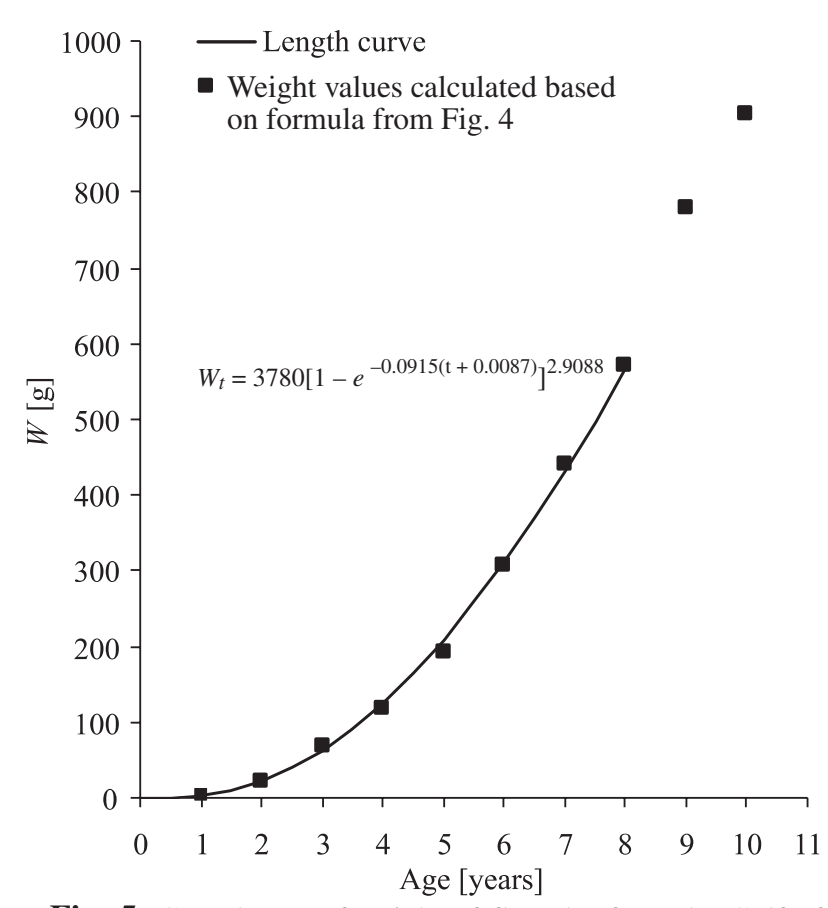

Fig. 5. Growth rate of weight of flounder from the Gulf of Gdańsk according to TL- $W$ relationship and modified von Bertalanffy equation

\section{DISCUSSION}

The flounder sampled from the Gulf of Gdańsk and characterised in the present paper, shows greatest variability in total length when compared to the samples of flounder captured in the Slupsk Furrow (Antoszek and Krzykawski 2004) and in the Pomeranian Bay (Antoszek and Krzykawski 2003).

The lowest variability in length was observed in the fish sample from the Słupsk Furrow, where flounder from older age-classes dominated, as components of spawning stock (Antoszek and Krzykawski 2004). This sample was also characterized by the greatest mean length of $31.4 \mathrm{~cm}$ $(29.8 \mathrm{~cm}$ in males, $32.1 \mathrm{~cm}$ in females).

The mean length of the fish from the Pomeranian Bay was $23.4 \mathrm{~cm}(23.1 \mathrm{~cm}$ in males, $23.6 \mathrm{~cm}$ in females).

Individuals collected in the Gulf of Gdańsk represented age-classes of I-X, with only a few fish from age-classes I and II. Age-classes III, IV, and V were the most abundant. The age of flounder from the Słupsk Furrow (Antoszek and Krzykawski 2004) ranged from four to ten, while in the sample from Pomeranian Bay (Antoszek and Krzykawski 2003) - from two to seven, with age-class II represented by a single fish.

The age of flounder, studied by the present authors at three earlier-mentioned areas of the southern Baltic Sea ranged from one to ten. Similar age structure was observed by other researchers (Fesolowicz and Wiktor 
1959, Cięglewicz 1947, 1972, 1973, 1974, Cięglewicz and Netzel 1978, Kuczyński 1992, 1995, 1996, Draganik and Kuczyński 1993, 1996, Kosior and Kuczyński 1995).

The absence of younger fish in the samples studied was obviously the affect of the protective regulations imposed on the flatfish catches in the Polish Exclusive Economic Zone, translating into bigger mesh-size in the coastal flounder gill-nets used by local fishermen (Kuczyński 1995). An additional factor affecting the presence of young fish in the samples studied is the zonal distribution of this species. The fish for the presently reported study were captured at the depth below $10 \mathrm{~m}$, whereas the youngest flounder occur in the shallow coastal waters. To collect young specimens, Cięglewicz (1935) sampled areas not deeper than 1.5 m, with a Peterson's fishing net. Malorny (1990) caught juveniles in the coastal zone, at the depth range of $0.5-1 \mathrm{~m}$.

In the presently reported study, from the Gulf of Gdańsk, males were more common than females (113 males, 86 females). The predominance of males in this area, although not so distinct, was also observed by Cięglewicz (1972, 1973). It could be affected by the sampling period (May-August). At that time the fish were on their way back from the spawning grounds in the Gdańsk Deep, where males remain longer than females (Reimann 1959). The above observations are consistent with Fesołowicz and Wiktor's (1959) conclusions on the predominance of males on the fishing grounds in the summer season. It was also reflected in the sample from the Słupsk Furrow (Antoszek and Krzykawski 2004), where females dominated in older year-classes.

It is evident from the comparison of the mean lengths $\mathrm{c}$ back-calculated from the otolith reading, in the sample examined, that the mean annual increments of length tend to decrease with the increasing age of fish. Antoszek and Krzykawski (2003, 2004) found out similar phenomenon in flounder captured in the Pomeranian Bay and Słupsk Furrow. In each of the areas compared, the intensive length increments are observed, particularly in the first 3 years of life, and then, with some fluctuations, a progressive decline with the increasing age of fish is recorded. These fluctuations could be affected by a low number of fish from older age-classes. The analysis of growth rates based on length of fish from the Gulf of Gdańsk, determined for both sexes, showed that in the first 3 years of life females grew slower, then in contrast, males had lower rate of growth in the consecutive years (Tables 2 and 3). Similar observations were presented by Cięglewicz (1947).

The fish from the Pomeranian Bay showed a faster growth rate in the first four years in comparison to flounder from Gulf of Gdańsk. It should be emphasized that, in spite of different procedures used, the similar tendency was observed by Cięglewicz $(1935,1947)$. In the following years (i.e. from the fifth year of life) a faster growth rate was observed in flounder from the Gulf of Gdańsk.

A faster growth rate of length in the first- and last years of life was recorded in flounder from the Gulf of Gdańsk than in Słupsk Furrow, whereas in the fourth-, fifth-, and sixth years of life flounder from the Słupsk Furrow demonstrated a faster rate of growth. The differences between the growth rates of flounder from individual areas may result from the different thermal conditions which strongly affect the growth rate of this species (Cięglewicz 1962, Cięglewicz and Hoppe 1970). In summer season, the highest average temperatures are recorded in the surface waters of the Pomeranian Bay, slightly lower ones - in the Gulf of Gdańsk, and the lowest - in the Słupsk Furrow area. It is evident, particularly in the case of young flounder (which prefer warm coastal waters) that temperature affects their rate of growth. That is probably why the fastest growth rate of flounder in the first years of life is observed in fish sampled from the Pomeranian Bay, slower in fish from the Gulf of Gdańsk, and the slowest in flounder from the Słupsk Furrow. In their more-advanced age the thermal factor is undoubtedly less significant, because adult fish clearly prefer deeper waters, much colder, where the temperature changes are not so distinct.

The growth rate based on length is demonstrated, fitted with the von Bertalanffy growth model for compared samples from three locations in the southern Baltic (Fig. 6).

Based on analysis of the results obtained from these locations, it can be concluded that the growth rate of length established with the von Bertalanffy equation, in the first years of life is the fastest in the western part of Polish Baltic waters, then it gradually decreases towards the east. Hence in the first years a higher growth rate of length is noted in flounder from the Pomeranian Bay, slower in fish from the Słupsk Furrow, and the slowest in fish from the Gulf of Gdańsk. As the fish get older, however, the opposite tendency is observed.

Fig. 7 shows the growth rates based on weight calculated with the modified von Bertalanffy model, in flounder from the three locations compared. Flounder from the Gulf of Gdańsk showed a slower growth rate of weight in the first years of life when compared to fish from the Pomeranian Bay; then this tendency (similarly like in the case of length growth) was inverted.

The greatest weight growth rate was noted in the sample of flounder from the Słupsk Furrow. It should be emphasized, however, that sampling in this location was performed on the spawning ground. Therefore the individuals examined were older and bigger than in the remaining locations, moreover, the weight of matured gonads was considerably high. These factors, as well as the predominance of females in the sample, usually bigger than males (Antoszek and Krzykawski 2004), undoubtedly affected the growth rate of weight in fish from this location.

The differences stated both in growth rates based on length and weight, as well as in the biometric characters (Antoszek and Krzykawski 2005) amongst flounder from the Pomeranian Bay, the Słupsk Furrow, and the Gulf of Gdańsk areas, may indicate that they represent separate stocks (populations). 


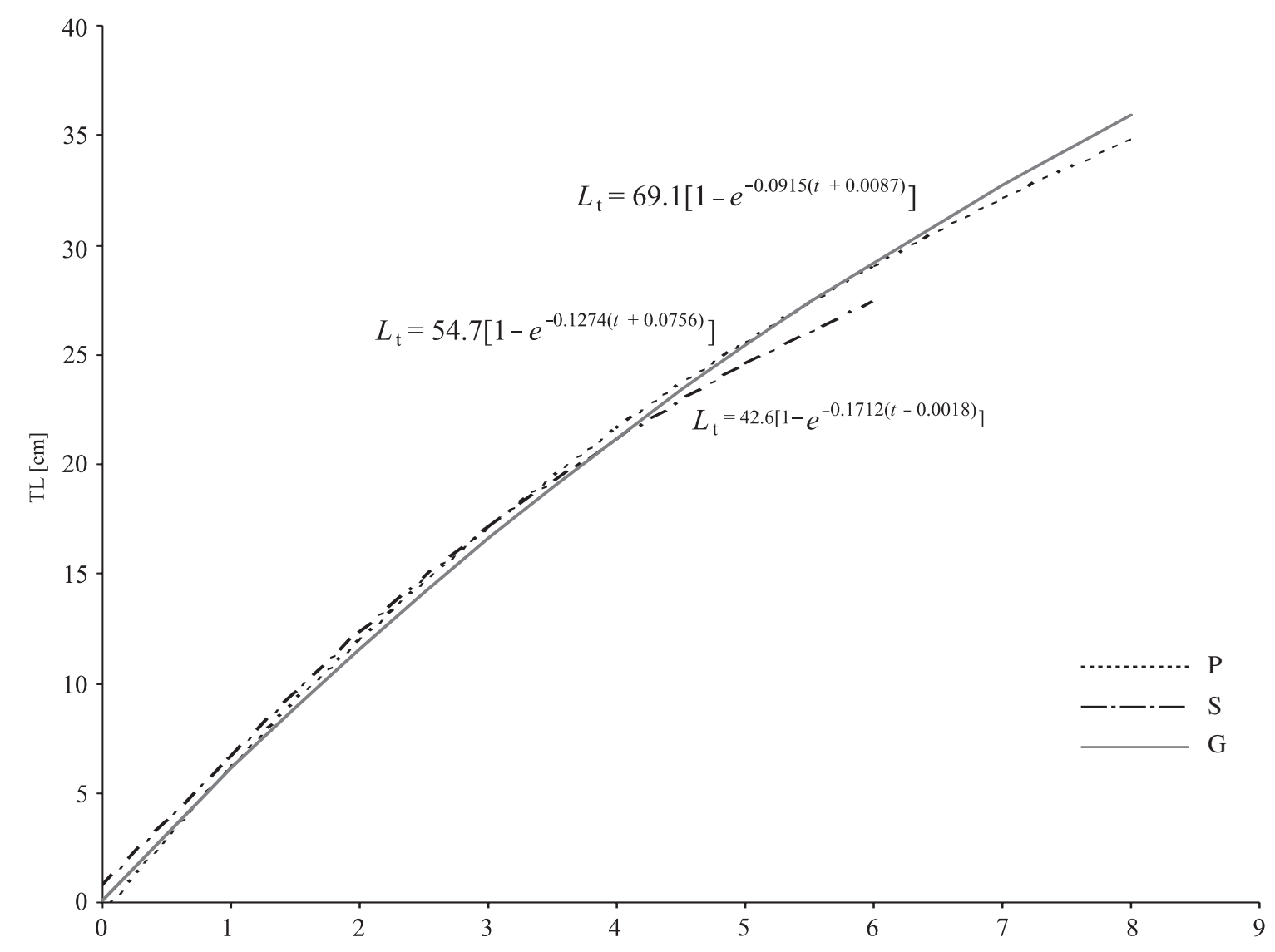

Fig. 6. Curves of length growth of flounder from Gulf of Gdańsk, Pomeranian Bay, and Słupsk Furrow areas according to v. Bertalanffy equation; P, Pomeranian Bay (Antoszek and Krzykawski 2003); S, Słupsk Furrow (Antoszek and Krzykawski 2004); G, Gulf of Gdańsk

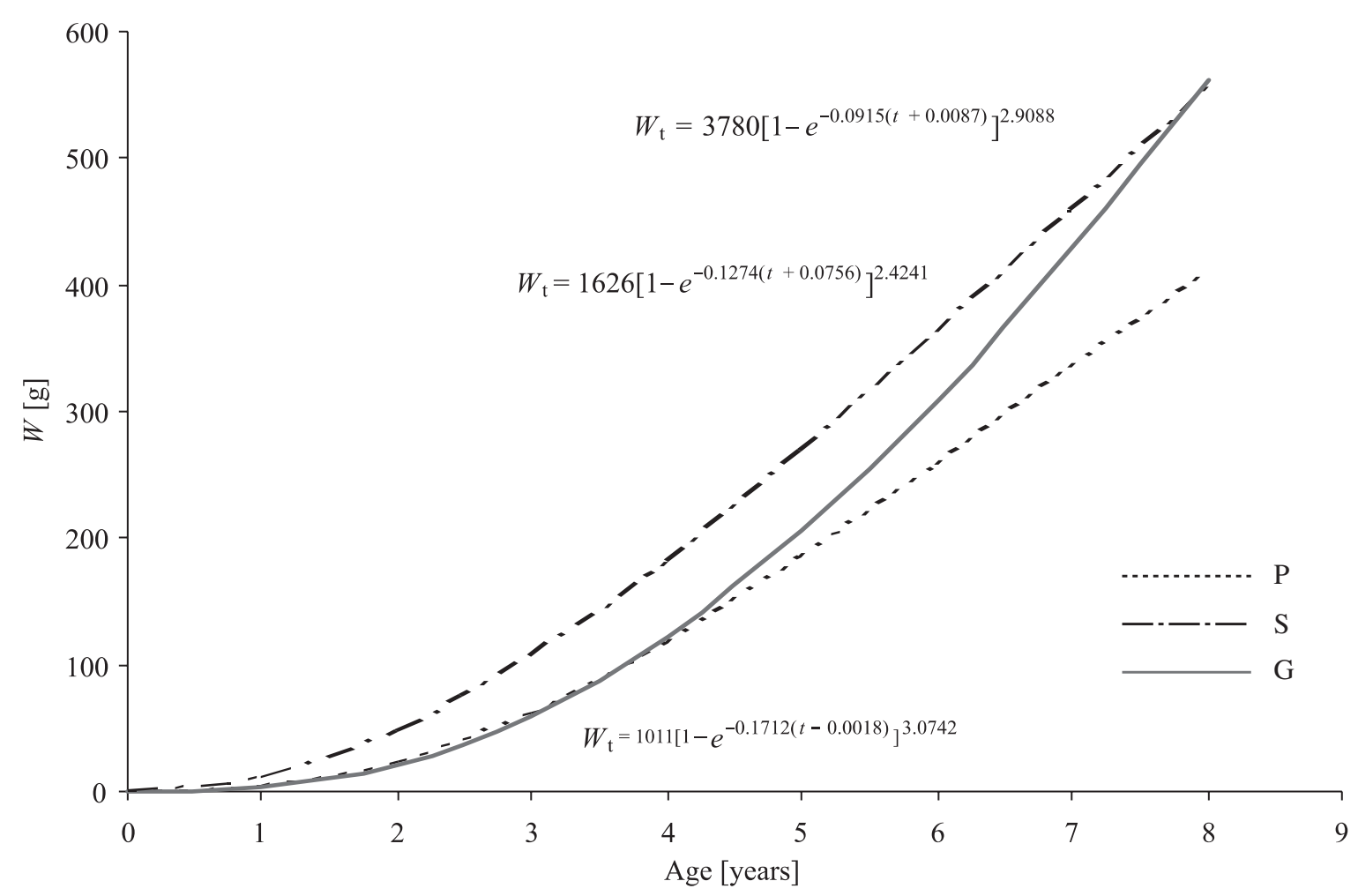

Fig. 7. Comparison of curves of weight growth of flounder from the Gulf of Gdańsk, Słupsk Furrow, and Pomeranian Bay areas, according to von Bertalanffy equations; P, Pomeranian Bay (Antoszek and Krzykawski 2003); S, Słupsk Furrow (Antoszek and Krzykawski 2004); G, Gulf of Gdańsk 


\section{REFERENCES}

Anonymous, 2004. C-27. In: Fishery statistics-capture production. FAO, Roma 94 (1): 405-409.

Antoszek A., Krzykawski S., 2003. Biomorphometry and growth rate of the flounder Platichthys flesus (L., 1758) from the Pomeranian Bay area. Acta Scientiarum Polonorum, seria Piscaria 2 (1): 3-26.

Antoszek A., Krzykawski S., 2004. Morphometry and growth rate of the flounder Platichthys flesus (L., 1758) from the Słupsk Furrow (southern Baltic). Acta Scientiarum Polonorum, seria Piscaria 3 (1-2): 3-22.

Antoszek A., Krzykawski S., 2005. Morphometry of flounder Platichthys flesus (L., 1758) from the Gulf of Gdansk (southern Baltic). Acta Scientiarum Polonorum, seria Piscaria 4 (1-2): (in press).

Cięglewicz W., 1935. Wzrost storni (Platichtchys flesus) poławianej w Zatoce Gdańskiej i w Zachodnim Bałtyku. [The growth rate of flounder (Platichthys flesus) captured in the Gulf of Gdańsk and in Western Baltic.] Archiwum Hydrobiologii i Rybactwa 9: 108-121. (In Polish.)

Cięglewicz W., 1947. Wędrówki i wzrost znakowanych storni w Zatoce Gdańskiej i Basenie Bornholmskim. [Migrations and growth of tagged flounder in the Gulf of Gdańsk and in the Bornholm Basin.] Archiwum Hydrobiologii i Rybactwa C 13: 105-135. (In Polish.)

Cięglewicz W., 1962. Charakterystyka biologiczna połowów storni (Platichtchys flesus L.) w Zatoce Gdańskiej. [Biological characteristics of the flounder catches in the Gulf of Gdańsk.] Prace Morskiego Instytutu Rybackiego, seria Oceanografia i Ichtiologia A 11: 201-223. (In Polish.)

Cięglewicz W., 1972. Charakterystyka polskich połowów storni (Platichtchys flesus L.) w południowym Bałtyku w 1971 roku. [Characteristics of Polish catches of the flounder (Platichthys flesus L.) in the southern Baltic in 1971.] Ekosystemy Morskie, seria Ichtiologia, Gdynia (3): 83-101. (In Polish.)

Cięglewicz W., 1973. Charakterystyka polskich połowów storni Platichtchys flesus (L.) w południowym Bałtyku w 1972 roku. [Characteristics of Polish catches of the flounder Platichthys flesus (L.) in the southern Baltic in 1972.] Ekosystemy Morskie, Ichtiologia, Gdynia (8), 57-72. (In Polish.)

Cięglewicz W., 1974. Charakterystyka polskich połowów storni (Platichtchys flesus L.) w południowym Bałtyku w 1973 roku. [Characteristics of Polish catches of the flounder (Platichthys flesus L). in the southern Baltic in 1973.] Ekosystemy Morskie, Ichtiologia, Gdynia (13): 69-87. (In Polish.)

Cięglewicz W., Draganik B., Żukowski Cz., 1969. Charakterystyka wzrostu storni (Platichtchys flesus L.) i skarpia (Scophthalmus maximus L.) za pomocą równania von Bertalanffy'ego. [Growth pattern of flounder (Platichthys flesus L.) and turbot (Scophthalmus maximus L.) by means of von Bertalanffy model.] Prace Morskiego Instytutu Rybackiego A 15: 121-132. (In Polish.)

Cieglewicz W., Hoppe G., 1970. The relation between the water temperature and the rate of growth of flounder Platichtchys flesus (L.) in Gdańsk Bay. Acta Ichthyologica et Piscatoria 1: 67-72.

Cięglewicz W., Netzel J., 1978. Analiza biologiczno-eksploatacyjna polskich połowów storni (Platichtchys flesus L.) w Południowym Bałtyku w latach 1971-1974. [Biological and exploitation analysis of Polish catches of the flounder (Platichthys flesus L.) in the southern Baltic within 1971-1974.] Studia i Materiały, Morski Instytut Rybacki A 20: 156-180. (In Polish.)

Draganik B., Kuczyński J., 1993. A review of growth rate of the Baltic flounder (Platichtchys flesus L.) derived from otolith measurements. Biuletyn Morskiego Instytutu Rybackiego 3 (130): 21-36.

Draganik B., Kuczyński J., 1996. Eksploatacja zasobów płastug w polskich obszarach morskich w 1995 r. [Exploitation of flatfish resources in Polish sea waters in 1995.] pp. 113-117. In: Raport Morskiego Instytutu Rybackiego, Gdynia 1995. (In Polish.)

Fesołowicz W., Wiktor J., 1959. Płastugi w polskich połowach przybrzeżnych w Zatoce Pomorskiej. [Flatfishes in the Polish coastal catches in the Pomeranian Bay.] Prace Morskiego Instytutu Rybackiego A 10: 383-402. (In Polish.)

Kosior M., Kuczyński J., 1995. Liczebność ikry storni (Platichtchys flesus L.) południowego Bałtyku w 1993r. [Abundance of eggs of flounder (Platichtchys flesus L.) from the southern Baltic.] pp. 249-251. In: Raport Morskiego Instytutu Rybackiego 1993-1994. (In Polish.)

Kuczyński J., 1992. Stornia (Platichtchys flesus L.). Połowy i stan zasobów dorszy i storni w Bałtyku (1980-1990). [The flounder (Platichthys flesus L.). Catches and condition of resources of cod and flounder in the Baltic Sea (1980-1990).] Studia i Materiały, Morski Instytut Rybacki B 59: 41-63. (In Polish.)

Kuczyński J., 1995. Zasoby bałtyckich ryb płaskich eksploatowanych przez polskie rybołówstwo w $1994 \mathrm{r}$. [Resources of Baltic flatfish exploited by Polish fisheries in 1994.] pp. 265-278. In: Raport Morskiego Instytutu Rybackiego, Gdynia 1993-1994. (In Polish.)

Kuczyński J., 1996. Charakterystyka polskich połowów storni (Platichtchys flesus L.) w południowym Bałtyku w 1995 r. [Characteristics of Polish catches of the flounder (Platichthys flesus L.) in the southern Baltic in 1995.] pp. 161-170. Raport Morskiego Instytutu Rybackiego, Gdynia. (In Polish.)

Malorny K., 1990. Obserwacje narybku storni (P. flesus L.) występującego w strefie przybrzeżnej Zatoki Gdańskiej w latach 1982-1983. [Observations of the fry of flounder, (P. flesus L.), occurring in the coastal zone of the Gulf of Gdańsk within 1982-1983.] Zeszyty Naukowe Wydziału Biologii i Nauk o Ziemi Uniwersytetu Gdańskiego, seria Oceanografia 12: 43-58. (In Polish.)

Miłosz J., Baniewicz D., Skorupowski W., Grelowski A., 2003. Atlas połowów bałtyckich 2002. [Catch atlas of the Baltic Sea for 2002.] Morski Instytut Rybacki, Gdynia. (In Polish).

Minet P.J., 1973. Age and growth of the American plaice Hippoglossoides platessoides, of Cape Breton Island in ICNAF Subdivision $4 \mathrm{Vn}$. International Commission for the Northwest Atlantic Fisheries Research Bulletin 10: 99-105.

Reimann Z., 1959. Stornia (P. flesus L.,) w połowach w rejonie bornholmskim w latach 1951-1955. [Flounder (P. flesus L.,) in the catches in the Bornholm area within 1951-1955.] Prace Morskiego Instytutu Rybackiego A 10: 441-459. (In Polish.) 
Ricker W.E., 1975. Computation and interpretation of biological statistics of fish populations. Bulletin of the Fisheries Research Board of Canada 191: 1-382.

Vovk F., 1956. O metodike rekonstrukcji rosta ryb po cesue. [On the method of growth rate determination with scale- reading.] Trudy Biologiceskoj Stancii „Borok” 2: 252-392. (In Russian.)

Received: 23 May 2005

Accepted: 15 June 2005 